\title{
The changing oxidizing environment in London - trends in ozone precursors and their contribution to ozone production
}

\section{E. von Schneidemesser ${ }^{1,{ }^{*}}$, M. Vieno ${ }^{2,3}$, and P. S. Monks ${ }^{1}$}

${ }^{1}$ Department of Chemistry, University of Leicester, University Road, Leicester, LE1 7RH, UK ${ }^{2}$ NERC - Centre for Ecology \& Hydrology, Bush Estate, Penicuik, EH26 OQB, UK

${ }^{3}$ University of Edinburgh, School of GeoSciences, Crew Building, The King's Buildings, West Mains Road, Edinburgh, EH9 3JN, UK

*now at: Institute for Advanced Sustainability Studies, Berliner Strasse 130, 14467 Potsdam, Germany

Received: 25 November 2013 - Accepted: 23 December 2013 - Published: 16 January 2014 Correspondence to: E. von Schneidemesser (evonsch@gmail.com)

Published by Copernicus Publications on behalf of the European Geosciences Union.
London's changing oxidizing

environment

E. von Schneidemesser et al.

\section{Title Page}

Abstract Introduction

Conclusions References

Tables

Figures

14

$\rightarrow 1$

4

Back

Close 


\section{Abstract}

Ground-level ozone is recognized to be a threat to human health (WHO, 2003), have a deleterious impact on vegetation (Fowler et al., 2009), is also an important greenhouse gas (IPCC, 2007) and key to the oxidative ability of the atmosphere (Monks et al., 5 2009). Owing to its harmful effect on health, much policy and mitigation effort has been put into reducing its precursors - the nitrogen oxides $\left(\mathrm{NO}_{\mathrm{x}}\right)$ and non-methane volatile organic compounds (NMVOCs). The non-linear chemistry of tropospheric ozone formation, dependent mainly on $\mathrm{NO}_{\mathrm{x}}$ and NMVOC concentrations in the atmosphere, makes controlling tropospheric ozone complex. Furthermore, the concentration of ozone at 10 any given point is a complex superimposition of in-situ produced or destroyed ozone and transported ozone on the regional and hemispheric-scale. In order to effectively address ozone, a more detailed understanding of its origins is needed. Here we show that roughly half $\left(5 \mathrm{\mu g} \mathrm{m}^{-3}\right)$ of the observed increase in urban (London) ozone $\left(10 \mu \mathrm{g} \mathrm{m}^{-3}\right)$ in the UK from 1998 to 2008 is owing to factors of local origin, in particular, the change in $\mathrm{NO}: \mathrm{NO}_{2}$ ratio, $\mathrm{NMVOC}: \mathrm{NO}_{\mathrm{x}}$ balance, $\mathrm{NMVOC}$ speciation, and emission reductions (including $\mathrm{NO}_{\mathrm{x}}$ titration). In areas with previously higher large concentrations of nitrogen oxides, ozone that was previously suppressed by high concentrations of NO has now been "unmasked", as in London and other urban areas of the UK. The remaining half (approximately $5 \mathrm{\mu g} \mathrm{m}^{-3}$ ) of the observed ozone increase is attributed to non-local factors such as long-term transport of ozone, changes in background ozone, and meteorological variability. These results show that a two-pronged approach, local action and regional-to-hemispheric cooperation, is needed to reduce ozone and thereby population exposure, which is especially important for urban ozone.

\section{Introduction}

25 Ground-level and tropospheric ozone has been identified as one of the most harmful air pollutants in Europe today (EEA, 2013). While trends in peak ozone seem to be on
ACPD

$14,1287-1316,2014$

\section{London's changing oxidizing \\ environment \\ E. von Schneidemesser \\ et al.}

Title Page

Abstract

Introduction

Conclusions

References

Tables

Figures

14

$\Delta$

4

Back

Close 
the decline, everyday (mean) ozone concentrations and background ozone still show increasing trends (EEA, 2012; Jonson et al., 2006). Recent work on ozone trends in the UK and Europe have all noted the lack of decrease in concentration over the past decade, despite observed reductions in emissions of ozone precursors (RoTAP, 2012;

5 EEA, 2009; Derwent et al., 2010; Wilson et al., 2012). Furthermore, a recent compliance assessment in the UK noted that while the target values for maximum daily $8 \mathrm{~h}$ mean ozone were being met, exceedances were reported for the long-term ozone objective for human health across the entire UK (Choudrie et al., 2012). There has been recognition at the various levels of policy formation in the UK and Europe that 10 policy intervention has successfully reduced ozone precursors, and in many cases it has also reduced peak ozone concentrations (AQEG, 2009). Some attribute this lack of decline to stable or increasing background ozone (a pragmatic definition of which is ozone measured at a site without the influence of strong local effects) concentrations as the main culprit, while others consider a combination of that and other influences 15 (emission changes, changing $\mathrm{NO}: \mathrm{NO}_{2}$ ratio, meteorological variability, stratospherictropospheric exchange) are responsible (EEA, 2009; Derwent et al., 2007, 2010; Parrish et al., 2012; RoTAP, 2012; Wilson et al., 2012; Hess and Zbinden, 2013). The focus now seems to have shifted somewhat, calling for greater focus on action at the hemispheric scale, targeting background ozone levels (RoTAP, 2012). Our results would indicate however, that it is equally important to address local ozone formation. Many open questions regarding ozone changes and the underlying causes remain. We still do not have a complete picture as to the role of an increase in the $\mathrm{NO}_{2}$ : $\mathrm{NO}$ emission ratio caused by an increase in the share of diesel vehicles in Europe has played in ozone formation (Weiss et al., 2012; Carslaw et al., 2011). Or to what extent spatially (along roadsides, across urban areas, regionally) primary $\mathrm{NO}_{2}$ emissions affect ozone concentrations. Meteorology also plays a large role in local ozone concentration affecting deposition and transport (Vieno et al., 2010; Francis et al., 2011).

The local coupling of $\mathrm{NO}_{x}$ and $\mathrm{O}_{3}$ was established decades ago, recognizing that reductions in NO can contribute to increases in ozone (Kley et al., 1994). In areas of

\section{ACPD}

$14,1287-1316,2014$

London's changing oxidizing

environment

E. von Schneidemesser

et al.

Title Page

Abstract

Introduction

Conclusions

References

Tables

Figures

14

$\Delta \mathbf{I}$

4

Back

Close

Full Screen / Esc

Printer-friendly Version

Interactive Discussion 
high $\mathrm{NO}_{\mathrm{x}}$, as is often observed in urban areas, ozone levels can be suppressed through the following reaction:

$\mathrm{NO}+\mathrm{O}_{3} \rightarrow \mathrm{NO}_{2}+\mathrm{O}_{2}$

This phenomenon, sometimes dubbed " $\mathrm{NO}_{x}$ titration", thereby leads to the counterintuitive effect that reducing $\mathrm{NO}_{\mathrm{x}}(\mathrm{NO})$ reduces the amount of ozone being suppressed and actually increases ozone (Heal et al., 2013).

In this work a combination of observational data and modeling is used to tease out a more detailed understanding with respect to the underlying causes of changes in ozone concentrations, using the London area and the UK as a case study. We show that local ozone production in urban areas of the UK is significantly influenced by the changing chemistry and emission reductions of ozone precursor compounds locally. We aim to parse out not only the role of decreasing NO, but the changing balance in the chemical regime of the ozone precursors, $\mathrm{NO}_{\mathrm{x}}$ and NMVOCs, vs. simple emission reductions if the oxidizing environment had remained as was. These changes are influencing the increases in ground level ozone in the UK, regionally, but especially around urban areas and road networks. These results are also likely to be relevant for urban areas throughout Europe, and possibly (traffic dominated) urban areas everywhere.

\section{Methods}

\subsection{Monitoring data, trends, and reactivity}

The UK and London in particular, has an extensive network of long-term air quality monitoring sites (http://uk-air.defra.gov.uk). Hourly data from 17 roadside, urban center, suburban, and urban background monitoring stations in London, and 20 largely urban background and rural sites across Southeast England were used. The time period considered was 1 January 1998 to 31 December 2009. The distribution of sites

London's changing oxidizing

environment

E. von Schneidemesser et al.

Title Page

Abstract Introduction

Conclusions

References

Tables

Figures

14

$\rightarrow I$

$<$

Back

Close

Full Screen / Esc

Printer-friendly Version

Interactive Discussion 
is shown in Fig. 1. The London sites, listed in Table 1, include ozone and ozone precursor $\left(\mathrm{NO}_{2}, \mathrm{NO}, \mathrm{CO}\right)$ data. For Marylebone Road and Eltham, data for speciated NMVOCs were also available, however for Eltham only from late 2003 onwards. These data included 26 non-oxygenated non-methane $\mathrm{C}_{2}-\mathrm{C}_{8}$ hydrocarbon species. Informa5 tion about the monitoring sites (classification, data coverage, location, trends and trend $p$ values) is included in Table S1, further details and site descriptions can be found at http://uk-air.defra.gov.uk/networks/. Data processing for all species was done using $R$ and openair (Team, 2008; Carslaw and Ropkins, 2012).

Data distributions were assessed and determined to be log-normal using q-q plots. 10 Therefore, trends were calculated by fitting a simple linear fit to the natural log of the data. The slope was then interpreted as a percent decrease per year (Parrish et al., 2009). Log-normalized data trends were assessed for all data using the Mann Kendall function in openair (Carslaw and Ropkins, 2012). Ninety-fifth percentile confidence intervals and statistical significance were determined for all trends. All trend analysis 15 required $50 \%$ of possible hourly data each month to be present in order for a trend to be calculated; all trends, except those of VOCs, were deseasonalized. London average trends include all hourly data available for all sites listed in Table 1. For comparison, the trends for an alternative London average which included only the data from the 9 sites that have data for all species $\left(\mathrm{NO}_{2}, \mathrm{NO}, \mathrm{CO}\right.$, and $\left.\mathrm{O}_{3}\right)$ were calculated and the results showed negligible differences.

The total reactivity with respect to $\mathrm{OH}\left(R_{\mathrm{OH}}\right)$ was calculated as the sum of the individual $\mathrm{OH}$ reactivities of NMVOCs and nitrogen dioxide. Of the sites where VOC data were available (Marylebone Road and Eltham), only Marylebone Road also had CO data. For this reason, total $\mathrm{OH}$ reactivity values do not include $\mathrm{CO}$. The $R_{\mathrm{OH}}$ values were calculated by multiplying the compound concentration by the corresponding $\mathrm{OH}$ reaction rate coefficients. This method of determining the relative importance of the atmospheric emission species to potential ozone formation has been well-established (Gilman et al., 2009; Goldan et al., 2004; Shao et al., 2009). The methodology followed for the calculation and the $\mathrm{OH}$ reaction rate coefficients used were done following Gilman et al. (2009)

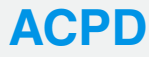

$14,1287-1316,2014$

London's changing oxidizing

environment

E. von Schneidemesser

et al.

Title Page

Abstract

Introduction

Conclusions

References

Tables

Figures

14

$>1$

4

Back

Close

Full Screen / Esc

Printer-friendly Version

Interactive Discussion 
and references therein. In order to scale up the measured NMVOCs to calculate an estimated sum of "total NMVOCs" (including those species not measured), emission inventory data were used from the UK National Atmospheric Emission Inventory (NAEI) of NMVOCs. This was done so as not to underestimate the contribution of NMVOCs 5 to the total reactivity. The compounds for which data were available from the monitoring sites that overlapped with speciated emission inventory data (18 compounds) were summed and a ratio determined relative to the total NAEI NMVOC emissions for each year. This was then applied to the measured data to estimate total NMVOCs, as if all species had been measured (this scaled-up estimate is implied when referring to "total 10 NMVOCs" unless explicitly stated otherwise). The same procedure was used for the reactivity calculations, except that total photochemical ozone creation potential (POCP) weighted NAEI emissions were used to account for the differences in reactivity.

\subsection{Modeling}

The atmospheric chemistry transport model (ACTM) used for this work is a one-way 15 nested regional application of the EMEP MSC/w model version rv3.8 (Simpson et al., 2012) and is referred to hereafter as EMEP4UK (Vieno et al., 2010). The EMEP4UK model meteorological driver is the Weather Research Forecast (WRF) model version 3.1.1 (www.wrf-model.org). The model horizontal resolution scales down from $50 \mathrm{~km}$ $\times 50 \mathrm{~km}$ in the main EMEP "Greater European" domain to $5 \mathrm{~km} \times 5 \mathrm{~km}$ for the do20 main covering the British Isles. The vertical resolution ranges from the surface up to $\sim 16 \mathrm{~km}$ at the top of the vertical domain. Anthropogenic emissions of $\mathrm{NO}_{\mathrm{x}}, \mathrm{NH}_{3}$, $\mathrm{SO}_{2}$, primary $\mathrm{PM}_{2.5}$, primary $\mathrm{PMcoarse}$ (the difference between $\mathrm{PM}_{10}$ and $\mathrm{PM}_{2.5}$ ), CO, and non-methane volatile organic compounds (NMVOC) are included. The NMVOC emissions are thereafter speciated into individual VOCs. The spatial distribution of the anthropogenic emissions and their injection heights and times were determined by selected nomenclature for sources of air pollution (SNAP) sectors. The 10 SNAP sectors used in the EMPE4UK model are: combustion in energy and transformation industries, non-industrial combustion, industrial combustion, production processes, extraction and
ACPD

$14,1287-1316,2014$
London's changing oxidizing environment
E. von Schneidemesser et al.

Title Page

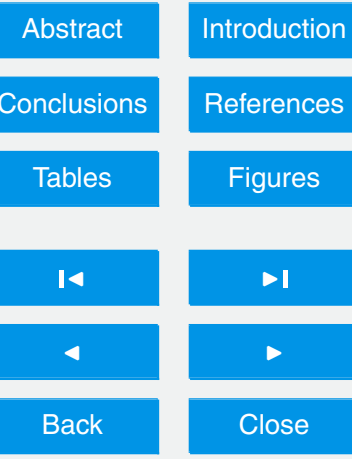

Full Screen / Esc

Printer-friendly Version

Interactive Discussion 
distribution of fossil fuels, solvent use, road traffic, other mobile sources (trains, planes, ships), waste treatment and disposal, agriculture, nature. The number of individual VOCs represented depends on the chemical mechanism chosen. For this work the CRIv2 R5 (Jenkin et al., 2008) chemical mechanism is used. A detailed NMVOC spe5 ciation for 25 individual VOCs is derived from observations at the AURN Marylebone road site. Moreover, the $\mathrm{NO}_{\mathrm{x}}$ speciation $\left(\mathrm{NO}\right.$ and $\left.\mathrm{NO}_{2}\right)$ is also derived from observations at Marylebone road.

For the UK, emissions values are taken from the National Atmospheric Emission Inventory (NAEl, http://naei.defra.gov.uk) at $1 \mathrm{~km}^{2}$ resolution and aggregated to $5 \mathrm{~km} \times$ $105 \mathrm{~km}$ resolution. For the rest of the outer domain, the model uses the EMEP $50 \mathrm{~km} \times$ $50 \mathrm{~km}$ resolution emission estimates provided by the Centre for Emission Inventories and Projections (CEIP, http://www.ceip.at/). Emissions estimates for international shipping (ENTEC, 2010) are aggregated to $5 \mathrm{~km} \times 5 \mathrm{~km}$ for those emissions within the inner domain. Biogenic emissions of isoprene are calculated in the model for every grid-cell,

and at every model time-step, using $2 \mathrm{~m}$ air temperature and photosynthetically active radiation.

Four experiments were carried out with the ACTM:

a. Base case scenario for the year 2008 , referred to hereafter as "2008 base case run" b. As experiment A but the UK 2008 emissions estimates were rescaled to the total for each SNAP sector category to the year 1998; the NMVOC and $\mathrm{NO}_{\mathrm{x}}$ speciation were derived from the 1998 observations, referred to hereafter as "1998 base case run"

c. As experiment B but the total emissions have been normalized to the year 2008 total, referred to hereafter as "alternate emissions run"

d. As experiment A, with the exception that the 1998 NMVOC speciation was applied, referred to hereafter as "VOC speciation run".
ACPD

14, 1287-1316, 2014

London's changing

oxidizing

environment

E. von Schneidemesser

et al.

Title Page

Abstract

Introduction

Conclusions

References

Tables

Figures

14

$\triangleright \mathbf{I}$

4

Back

Close

Full Screen / Esc

Printer-friendly Version

Interactive Discussion
D

ieractive Discussion

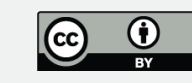




\subsection{Comparison of observed and model data}

Five London sites (Bloomsbury, Eltham, Hillingdon, North Kensington, and Marylebone Road) that had sufficient data coverage for ozone for the June, July, August (JJA) period in 1998 and 2008 were chosen for comparison with the model outputs. (Monitoring 5 at a number of the other sites stopped just short of 2008 and were therefore not included; as noted in Table S1.) Averages across these sites are included as part of the comparison. However, Marylebone Road, which was a roadside site and often exhibited different behavior from the other 4 sites, and was therefore not included. As mentioned previously, a roadside site is more representative of fresh emissions and not the conditions in the city overall. The model would not capture these details and therefore comparisons to the model results do not include the Marylebone Road site.

For comparison, the UK regulatory air quality target value for ozone was used maximum daily $8 \mathrm{~h}$ mean. As per the regulatory definition, the daily max is determined from the running $8 \mathrm{~h}$ mean calculated from the hourly measurement data. The max daily $158 \mathrm{~h}$ mean value is not to exceed $120 \mathrm{\mu g} \mathrm{m}^{-3}$ on more than 25 days per calendar year, averaged over 3 yr (www.legislation.gov.uk/uksi/2010/1001/contents/made; Schedule 3 - Target values; accessed May 2013).

Figure 2 shows the modeled (red line) daily maximum $8 \mathrm{~h}$ ozone vs. observations (black line) for Eltham, North Kensington, Marylebone Road, and Mace Head (baseline/background ozone). The model does well to capture the variability and magnitude of the daily maximum $8 \mathrm{~h}$ ozone for observation sites sampling air representing urban background (Eltham, North Kensington) and relatively clean sites such as Mace Head. The model overestimates the daily maximum $8 \mathrm{~h}$ ozone at a kerbside location such as Marylebone Road where the very high traffic $\mathrm{NO}_{\mathrm{x}}$ emissions are not well represented

\section{ACPD}

$14,1287-1316,2014$

\section{London's changing oxidizing \\ environment \\ E. von Schneidemesser \\ et al.}

\section{Title Page}

Abstract

Conclusions

Tables

14

4

Back

Full Screen / Esc 


\section{Results and discussion}

\subsection{Trends}

The observed trends at sites throughout London show that $\mathrm{NO}_{2}, \mathrm{NO}$, and $\mathrm{CO}$ have all been decreasing over the past decade (with the exception of $\mathrm{NO}_{2}$ at the kerbside site 5 at Marylebone Road, MR) as shown in Table 1. Carbon monoxide trends showed the largest percent per year decreases, with a London average of $-9 \%$ per year, followed by $\mathrm{NO}$ and $\mathrm{NO}_{2}$, with London averages of $-6 \%$ and $-1 \%$ per year, respectively. The largest decreases for all species were observed at the roadside/kerbside sites, which are most reflective of "fresh" traffic emissions.

10 A succession of Euro tail pipe emissions regulations applied to passenger vehicles has implemented limits on total hydrocarbon emissions starting in 2000 with the Euro III regulations, followed by further restrictions from Euro IV (2005) and Euro $V$ (2009). Non-methane volatile organic compound measurements from Marylebone Road showed decreases of $-11 \%$ per year at $99.9 \%$ significance for total NMVOCs; the sum of the measured NMHCs (not the NAEI scaled-up estimated total) decreased by $-13 \%$ per year (99.9\% significance). The decreasing trend at Eltham (for 2003 onwards only) was not statistically significant. For more detailed information on the trends of the individual NMVOCs, see von Schneidemesser et al. (2010).

London also implemented a number of additional measures to combat congestion and air pollution in the city center. These measures included the implementation of the congestion charging zone (CCZ) in central London in early 2003 and other traffic congestion and emissions reduction measures across the city, including additional bus lanes, the use of larger buses, particle traps on diesel buses, increased bus frequency, and changes to traffic light phases (Atkinson et al., 2009).

The $\mathrm{NO}$ trends decreased at a significantly faster rate than those of $\mathrm{NO}_{2}$, in most cases at over twice the rate, with greater differences at the sites closest to the traffic emission sources and lesser differences farther from the traffic emissions (see Table 1). The only positive trend in $\mathrm{NO}_{2}$ for this time period among the sites was at Marylebone

London's changing oxidizing environment

E. von Schneidemesser et al.

Title Page

Abstract Introduction

Conclusions

References

Tables

Figures

14

$\Delta \mathbf{I}$

4

Back

Close 
Road ( $+1.6 \%$ per year; $99.9 \%$ significance), a curbside site on a highly trafficked road on the boundary of the Congestion Charging Zone (CCZ) in central London. The data from Marylebone Road show a visible jump in concentration that occurred in concert with the implementation of emission reduction measures in early 2003 (Carslaw et al., 5 2006). If analyzed as two separate time periods (before and after January 2003), the trend at Marylebone Road was decreasing at a rate of $-4.1 \%$ per year $(99.9 \%$ significance) before early 2003, whereas after, a $0 \%$ per year trend (not significant) in $\mathrm{NO}_{2}$ was observed. This change from reducing $\mathrm{NO}_{2}$ trends to a stagnation in concentration after 2003 may also be due to the increasing fraction of primary $\mathrm{NO}_{\mathrm{x}}$ emitted as $\mathrm{NO}_{2}$, which has been going up from $5 \%$ (mid-1990s) to closer to $20 \%$ (mid-2000s) as vehicle control technologies change (such as the implementation of particulate filters on diesel vehicles) (Carslaw, 2005). This would indicate that while the implemented changes may have positively influenced (reduced emissions) other species such as particulate matter, the effect on $\mathrm{NO}_{2}$ actually stopped the decreasing trend at Maryle-

\section{bone Road. These results are in agreement with a study quantifying the changes owing} to the congestion charging scheme for the two years before and after its implementation, which observed increases in $\mathrm{NO}_{2}$ and $\mathrm{O}_{3}$ after implementation from monitors within the CCZ (Atkinson et al., 2009). Two other sites in the CCZ, one roadside and one urban center site, show similar trends, while a third site in the CCZ, North Kensington (urban background) did not follow this pattern, showing a larger decreasing trend after early 2003. Of the remaining 11 sites outside of the CCZ no discernible pattern was found in the changes in the trends from before 2003 relative to 2003 onwards. This variability in trends indicates a complexity in capturing urban-scale trends and the importance of having a variety of monitoring sites. This phenomenon of sharper decreases in $\mathrm{NO}$ and lesser (or insignificant) decreases in $\mathrm{NO}_{2}$ concentrations was also observed in Germany and also attributed to the application of diesel particulate filters to diesel vehicles (Melkonyan and Kuttler, 2012). Quantitative comparison of trends is not straightforward owing to e.g., different time periods, units, etc.
ACPD

$14,1287-1316,2014$

London's changing oxidizing

environment

E. von Schneidemesser

et al.

Title Page

Abstract

Introduction

Conclusions

Tables

References

Figures

14

$\triangleright \mathbf{I}$

4

Back

Close

Full Screen / Esc

Printer-friendly Version

Interactive Discussion 
In contrast to the decreasing trends of the ozone precursor compounds (similar results have been observed across Europe, Colette et al., 2011) trends in urban (London) ozone were dominated by increasing trends over the past 10-12 yr, with the largest increases observed at the urban background sites, and an average London trend of $+1 \%$

5 per year. Recent non-quantitative results from Bigi and Harrison (2010) also observed a steady increase in ozone from 1996-2008 at the North Kensington site in London. All sites within London showed increasing trends, while data from the mainly rural and urban background sites surrounding London in southeast England ranged from $-3 \%$ per year to $+3 \%$ per year, see Fig. 1 (not all data sets were $10 \mathrm{yr}$ or longer, see Table $10 \mathrm{~S} 1$ in the Supplement for all site details and trend $p$ values). Generally, those sites that showed statistically significant increasing trends in $\mathrm{O}_{3}$ were in the downwind region (northeast) of London suggestive of a regional impact of London urban emissions on ozone in the south east UK (Fig. 1).

\subsection{Oxidizing environment}

15 These reductions in ozone precursor emissions and more specifically, the varying rates at which these reductions have been taking place have resulted in a change in the oxidizing environment of London's atmosphere. This change can be best demonstrated by examining the changes in reactivity of the ozone precursor compounds with respect to the $\mathrm{OH}$ radical $\left(R_{\mathrm{OH}}\right)$. While the amount of $\mathrm{O}_{3}$ produced depends on a number of 20 additional factors beyond $\mathrm{O}_{3}$ precursor levels, including meteorological conditions and oxidation mechanisms, this method does provide an estimation of the relative importance of the different compounds with respect to daytime photochemistry and oxidizing potential (ozone formation potential) (Carter, 1994; Gilman et al., 2009; Goldan et al., 2004; Shao et al., 2009). Figure 3 shows how the balance in $\mathrm{NO}_{2}: \mathrm{NMVOC}$ reactivity 25 has changed from 1998 to 2009 at the Marylebone Road site. While MR is a curbside site and therefore typically not representative of general conditions throughout a city, e.g. farther from emission sources, similar contributions to reactivity were found at Eltham (suburban site) and in Paris at an urban background site (for data see von
ACPD

$14,1287-1316,2014$
London's changing oxidizing
environment
E. von Schneidemesser et al.

Title Page

Abstract

Introduction

Conclusions

References

Tables

Figures

14

$>1$

4

Back

Close

Full Screen / Esc

Printer-friendly Version

Interactive Discussion 
Schneidemesser et al., 2010), which seems to indicate that this evolution might not be limited to only roadside locations. For MR, the fractional contribution of $\mathrm{NO}_{2}$ increased from $22 \%$ in 1998 to $62 \%$ in 2008 , while the total VOCs decreased from $77 \%$ in 1998 to $36 \%$ in 2008 . The overall reactivity decreased during this time period by $-8.3 \%$ per 5 year.

\subsection{Modeling - parsing out the influences}

The EMEP4UK model (Vieno et al., 2010) was employed to parse the influence of changing reactivity vs. simple emission reductions and their impact on urban and regional ozone. For precursor emissions, the change from the 1998 base case to the 102008 base case model runs showed reductions in $\mathrm{NO}, \mathrm{NO}_{2}$, and NMVOCs, as expected (not shown). The $\mathrm{NO}$ and $\mathrm{NO}_{2}$ reductions noticeably followed the road networks and urban areas, while the NMVOC reductions were more generally dispersed over the country. In agreement with the monitoring network trends for ozone the model showed increases in surface ozone from the 1998 base case to the 2008 base case, as shown in Fig. 4 for the summer. This ozone increase followed the road networks and urban areas most noticeably during the summer months, with surrounding and downwind areas showing ozone reductions.

To further investigate the breakdown in the cause of the increase in ozone, for greater insight into the attribution of factors contributing to local conditions, two additional 20 model runs were conducted: (1) where all conditions from the "1998 base case run" were retained, with the exception that the total amount of emissions was scaled down to the 2008 level (the alternate emissions run, as described in the methods section) which separates out the effect of the change in NMVOC speciation, $\mathrm{NO}: \mathrm{NO}_{2}$ ratio, and NMVOC : $\mathrm{NO}_{x}$ balance on ozone, and (2) where all conditions from the "2008 base plied (the VOC speciation run, as described in the methods section). The results for the additional runs are shown for June in Fig. 5. As for the change observed in the NMVOC emissions from 1998 to 2008, the change in speciation also resulted in a change that

ACPD

14, 1287-1316, 2014

London's changing oxidizing

environment

E. von Schneidemesser et al.

Title Page

Abstract Introduction

Conclusions

References

Tables

Figures

14

$\Delta \mathbf{I}$

4

Back

Close 
was generally dispersed across the UK and did not follow urban areas and road networks. These results will be discussed in more detail in the following section.

\subsection{Model comparison with observations}

The modeled change in summer ozone $\left(\Delta \mathrm{O}_{3}\right)$ from 1998 to 2008 was an increase of $55.0 \mu \mathrm{gm}^{-3}\left(\mathrm{sd} 2.3 \mu \mathrm{g} \mathrm{m}^{-3}\right.$ ) on average for the 4 London sites (BB, LE, HL, NK) for mean daily max $8 \mathrm{~h}$ ozone. In comparison, the change in the observed summer ozone for the same 4 London sites from 1998 to 2008 was $10 \mu^{-3}$ m $^{-3}\left(\mathrm{sd} 1.9 \mu \mathrm{gm}^{-3}\right.$ ) on average for mean daily max $8 \mathrm{~h}$ ozone. These results are summarized in Table 2 , which also

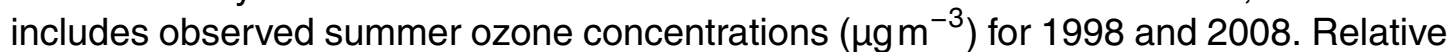

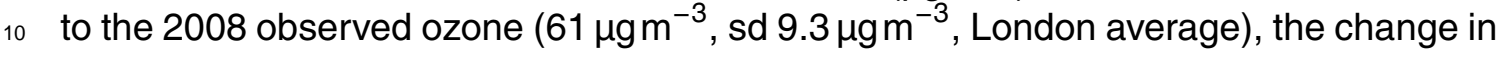
observed ozone represents about $16 \%$ of the observed concentration, and again about half as much ( $8 \%)$ for the change in modeled ozone. The modeled change in ozone $\left(5.0 \mu \mathrm{gm}^{-3}\right.$ on average for London) can be attributed to local conditions/production, while the remaining $5 \mathrm{\mu gm}^{-3}$ change in ozone not accounted for by the model, but

15 showing up in the observations can be attributed to non-local influence and other factors, such as changes in (long-range) transport of ozone, changes to background ozone, the influence of biogenic ozone, and the influence of meteorology and natural variability. We attribute these factors as such, because of the model run conditions that held the meteorology, boundary conditions, and spatial distribution constant between the 1998 and 2008 runs, which allowed their influence to be excluded. The local conditions cited earlier therefore include the reduction in emissions, the change in $\mathrm{NO}: \mathrm{NO}_{2}$ ratio, and the NMVOC speciation. Within the reduction in emissions, the change in chemical regime (NMVOC : $\mathrm{NO}_{\mathrm{x}}$ balance) is also included.

To distinguish between the factors of "local influence", the alternate emissions run and VOC speciation run results are considered. Taking the difference between the 2008 base case and the alternate emissions run separated out the effect of the VOC speciation, $\mathrm{NO}: \mathrm{NO}_{2}$ ratio, and $\mathrm{NMVOC}: \mathrm{NO}_{\mathrm{x}}$ balance, from simple emission reductions (i.e., if all emissions had been reduced at the same rate). What is shown is therefore the 1299
ACPD

14, 1287-1316, 2014

London's changing oxidizing

environment

E. von Schneidemesser et al.

Title Page

Abstract Introduction

Conclusions

References

Tables

Figures

14

$\triangleright \mathbf{I}$

4

Back

Close

Full Screen / Esc

Printer-friendly Version

Interactive Discussion 
effect of the change in NMVOC speciation, $\mathrm{NO}: \mathrm{NO}_{2}$ ratio, and $\mathrm{NMVOC}: \mathrm{NO}_{\mathrm{x}}$ balance contributed to the increases in ozone; again these changes were focused over the urban areas and road networks (Fig. 6). Quantitatively, this contribution to the increase in ozone over the London area was $1.3{\mu \mathrm{gm}^{-3}}\left(\mathrm{sd} 1.1 \mathrm{\mu g} \mathrm{m}^{-3}\right)$ on average for mean 5 daily max $8 \mathrm{~h}$ ozone (Table 2 ). This part of the contribution was smaller and more varied across the city, with the Hillingdon site showing a small decrease, while other sites still showed increases. Minor ozone increases outside of the UK (especially northern area) are shown in the 2008 base case minus alternate emissions run results, however, these slight increases end up dwarfed by the emission reductions so that the areas end 10 up with decreases in ozone when all modeled (local) factors are included (difference between the two base case runs).

The difference between the 2008 base case and the VOC speciation run illustrate the effect of the change in VOC speciation only. As can be seen in Fig. 5 and Table 2, the effect on ozone production from the change in VOC speciation was very 5 minor, resulting in a slight decrease in ozone from 1998 to 2008 (4 site London average: $-0.16 \mu \mathrm{gm}^{-3} \pm 0.02 \mu \mathrm{gm}^{-3}$ ). Although significant reductions in NMVOCs occurred over the time period, the relative speciation did not change much, as previous work has showed strong relationships between the NMVOCs and CO that were preserved through emission reductions (von Schneidemesser et al., 2010; Parrish et al., 2009; Warneke et al., 2012). Therefore large changes in ozone forming potential from changes within the NMVOC speciation were not expected.

Therefore, if we regard the change in VOC speciation as negligible, the difference between the change shown in the base case plots (Fig. 5, top right) and the change shown attributed to the change in $\mathrm{VOC}: \mathrm{NO}_{\mathrm{x}}$ ratio and $\mathrm{NO} / \mathrm{NO}_{2}$ ratio (Fig. 5, bottom left), would indicate that simple emission reductions have contributed to increases in ozone over the urban areas/road networks on the order of a few $\mu \mathrm{gm}^{-3}\left(<5\right.$ and $\left.>1 \mu \mathrm{gm}^{-3}\right)$. The change in $\mathrm{VOC}: \mathrm{NO}_{\mathrm{x}}$ ratio and $\mathrm{NO} / \mathrm{NO}_{2}$ ratio contributed (based on the 4 London sites) approximately $1 \mathrm{\mu gm}^{-3} \pm 1 \mathrm{\mu gm}^{-3}$ (Table 2). Given that the London area is (and many other urban areas are) typically $\mathrm{VOC}$-limited/ $\mathrm{NO}_{\mathrm{x}}$ saturated, within the emission

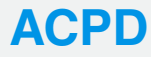

$14,1287-1316,2014$

London's changing oxidizing

environment

E. von Schneidemesser et al.

Title Page

Abstract Introduction

Conclusions

References

Tables

Figures

14

$\Delta \mathbf{I}$

4

Back

Close

Full Screen / Esc

Printer-friendly Version

Interactive Discussion ose teractive Discussion

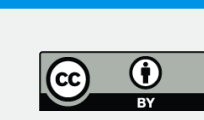


reductions is the "titration" effect, where the decreased $\mathrm{NO}_{\mathrm{x}}$ has led to increased ozone (or less ozone suppression). That a large portion of the local effect was a result of less titration of $\mathrm{O}_{3}$ and a VOC-limited environment is supported by the weekday-weekend differences observed in London (not shown). $\mathrm{NO}$ and $\mathrm{NO}_{2}$ concentrations at the week5 end were lower, while $\mathrm{O}_{3}$ concentrations at the weekend were higher than during the week. Furthermore, the difference between 1998 and 2008 concentrations is much greater for $\mathrm{NO}$ than for $\mathrm{NO}_{2} ; \mathrm{NO}_{2}$ also shows a greater decrease at the weekend in 2008 than in 1998. Similar results from observing the weekday-weekend effect on ozone concentrations were also documented previously in Sacramento, USA (Murphy 10 et al., 2007). Furthermore, in a model intercomparison study (Colette et al., 2011), the effect of anthropogenic emission reductions on ozone was investigated and, similar to these results, also found increases in ozone within the $\mathrm{NO}_{\mathrm{x}}$-saturated parts of northern Europe - southern UK, BeNeLux region, and Germany.

The decreases in ozone shown in the model results outside of the urban areas are 15 what one might expect to see from the reductions in primary emissions where conditions are not $\mathrm{NO}_{\mathrm{x}}$ saturated (again, without the influence of non-local factors). For example, the modeled difference from 1998 to 2008 base cases for winter months shows a spatially larger "unmasking" of ozone owing to the longer lifetime of $\mathrm{NO}_{\mathrm{x}}$ and less active photochemistry (Fig. 6). Results from Jonson et al., also found that for Europe in winter, both emissions and boundary conditions contribute to higher ozone levels (Jonson et al., 2006).

The effect of megacity emissions on the surrounding region can be significant, as shown in previous studies. For example, the importance of emission hot spots (in this case the two cities) to air quality in the extended East Mediterranean region was demonstrated by a modeling study that found enhanced ozone in rural sites in the areas around Athens, Greece and Istanbul, Turkey (Im and Kanakidou, 2012). Similarly, a model study found that precursor gases emitted in the urban center of Tokyo were transported downwind and resulted in enhanced ozone in areas 50-100 km distant, as well as general enhancements of daytime ozone during summer in the region

\section{ACPD}

14, 1287-1316, 2014

London's changing oxidizing

environment

E. von Schneidemesser

et al.

Title Page

Abstract

Introduction

Conclusions

Tables

References

Figures

14

$\Delta \mathbf{I}$

4

Back

Close

Full Screen / Esc

Printer-friendly Version

Interactive Discussion 
around Tokyo $(200 \mathrm{~km} \times 200 \mathrm{~km})$ (Kondo et al., 2010). Previous work has shown that local ozone formation driven from biogenic VOCs, at least in the London area, does not yet play an important role, even though anthropogenic emissions have decreased significantly (von Schneidemesser et al., 2011). That said, biogenic emissions could 5 contribute significantly to ozone formation as it is transported out of the city over more rural, vegetated areas (Tie et al., 2013).

Similar work from Jonson et al. (2006) considered the time period from 1990-2002, using the EMEP model to compare to measured trends in European surface ozone. Their scope however was much broader (all of Europe), and trends from mainly rural 10 and background sites were compared to model results which considered not only local (European) emissions, but also the influence of transport and natural variability. Their results "strongly suggested that ozone was affected by a combination of changes in European emission (mostly reductions) of precursor compounds and an increase in lateral boundary conditions," and that changes in ozone caused by European emissions 15 are largely superimposed on top of the global/hemispheric ozone trends (Jonson et al., 2006).

\section{Conclusions}

Using a combination of monitoring data and modeling has yielded new insights into the reasons for increases in ozone that have been observed in a number of urban areas despite successful reductions in primary emissions of ozone precursors. We attributed roughly half $\left(5 \mathrm{\mu g} \mathrm{m}^{-3}\right)$ of the observed increase in urban ozone $\left(10 \mathrm{\mu g} \mathrm{m}^{-3}\right)$ from 1998 to 2008 during the summer months to factors of local origin: the change in $\mathrm{NO}: \mathrm{NO}_{2}$ ratio, $\mathrm{NMVOC}: \mathrm{NO}_{x}$ balance, and NMVOC speciation, as well as emission reductions. The effects from a relatively minor change in VOC speciation had almost negligible effects on ozone production. Within the remaining local factors ( $\mathrm{NO}: \mathrm{NO}_{2}$ ratio, NMVOC : $\mathrm{NO}_{\mathrm{x}}$ balance and emission reduction), $\mathrm{NO}_{\mathrm{x}}$ titration (emission reduction) plays a significant role. In $\mathrm{NO}_{\mathrm{x}}$ saturated areas, ozone that was previously suppressed
ACPD

$14,1287-1316,2014$

\section{London's changing oxidizing environment \\ E. von Schneidemesser et al.}

Title Page

Abstract Introduction

Conclusions

References

Tables

Figures

14

$\Delta \mathbf{I}$

4

Back

Close

Full Screen / Esc

Printer-friendly Version

Interactive Discussion 
by high concentrations of NO has now been "unmasked", as in London and other urban areas of the UK, an effect that has long been recognized as suppressing $\mathrm{O}_{3}$ concentrations in urban areas. The remaining increase in ozone that was observed (approximately $5 \mathrm{\mu g} \mathrm{m}^{-3}$ ) was attributed to factors that are not controllable locally, such as (long5 term) transport of ozone, changes in background ozone, and meteorological variability. Results from a model ensemble study showed similar ozone increases in response to primary emission reductions over areas of northern Europe (Colette et al., 2011), suggesting that these results are likely applicable to other areas in Europe and not just the UK. Further reductions of primary ozone precursor emissions may yield higher ozone 10 in urban $\left(\mathrm{NO}_{\mathrm{x}}\right.$ saturated) areas in the short-term, but should also lead to ozone reductions in surrounding areas, as well as reductions in urban areas in the long-term. These local/regional policies should be paired with cooperation at the hemispheric-to-global scale to reduce background ozone levels and transboundary transport of ozone.

\section{Supplementary material related to this article is available online at http://www.atmos-chem-phys-discuss.net/14/1287/2014/ acpd-14-1287-2014-supplement.pdf.}

Acknowledgements. This study was funded in part by the European Commission under the seventh framework programme as part of the CityZen project (212095), as well as Pegasos (FP7-ENV-2010-265148). The UK monitoring network and data were supported by the Air and

20 Environmental Quality Division of the Department for Environment, Food, and Rural Affairs. We thank N. Carslaw (Univ. York) for initial consultations on box modeling, S. Henne for statistical analysis advice.

\section{References}

AQEG: Ozone in the United Kingdom, Department for the Environment, Food and Rural Affairs, London, 2009.

Atkinson, R. W., Barratt, B., Armstrong, B., Anderson, H. R., Beevers, S. D., Mudway, I. S., Green, D., Derwent, R. G., Wilkinson, P., Tonne, C., and Kelly, F. J.: The impact of the con-
ACPD

$14,1287-1316,2014$

\section{London's changing oxidizing \\ environment \\ E. von Schneidemesser et al.}

Title Page

Abstract

Introduction

Conclusions

References

Tables

Figures

14

4

Back

Close

Full Screen / Esc

Printer-friendly Version

Interactive Discussion 
gestion charging scheme on ambient pollution concentrations in London, Atmos. Environ., 43, 5493-5500, 2009.

Bigi, A. and Harrison, R. M.: Analysis of the air pollution climate at a central urban background site, Atmos. Environ., 44, 2004-2012, 2010.

5 Carslaw, D. C.: Evidence of an increasing $\mathrm{NO}_{2} / \mathrm{NO}_{\mathrm{x}}$ emissions ratio from road traffic emissions, Atmos. Environ., 39, 4793-4802, 2005.

Carslaw, D. C. and Ropkins, K.: Openair - an r package for air quality data analysis, Environ. Modell. Softw., 27-28, 52-61, 2012.

Carslaw, D. C., Ropkins, K., and Bell, M. C.: Change-point detection of gaseous and particulate traffic-related pollutants at a roadside location, Environ. Sci. Technol., 40, 6912-6918, 2006.

Carslaw, D. C., Beevers, S. D., Tate, J. E., Westmoreland, E. J., and Williams, M. L.: Recent evidence concerning higher $\mathrm{NO}_{\mathrm{x}}$ emissions from passenger cars and light duty vehicles, Atmos. Environ., 45, 7053-7063, 2011.

Carter, W. P. L.: Development of ozone reactivity scales for volatile organic compounds, J. Air

15 Waste Manage., 44, 881-899, 1994.

Choudrie, S., Kent, A., King, R., Loader, A., Martinez, C., Stedman, J., Willis, P., and Connolly, E.: Air Pollution in the UK 2011 - Compliance Assessment Summary, Department for Environment, Food and Rural Affairs, London, 2012.

Colette, A., Granier, C., Hodnebrog, Ø., Jakobs, H., Maurizi, A., Nyiri, A., Bessagnet, B., D'Angiola, A., D'Isidoro, M., Gauss, M., Meleux, F., Memmesheimer, M., Mieville, A., Rouïl, L., Russo, F., Solberg, S., Stordal, F., and Tampieri, F.: Air quality trends in Europe over the past decade: a first multi-model assessment, Atmos. Chem. Phys., 11, 11657-11678, doi:10.5194/acp-11-11657-2011, 2011.

Derwent, R. G., Simmonds, P. G., Manning, A. J., and Spain, T. G.: Trends over a 20 yr period 25 from 1987 to 2007 in surface ozone at the atmospheric research station, Mace Head, Ireland, Atmos. Environ., 41, 9091-9098, 2007.

Derwent, R. G., Witham, C. S., Utembe, S. R., Jenkin, M. E., and Passant, N. R.: Ozone in Central England: the impact of $20 \mathrm{yr}$ of precursor emission controls in Europe, Environ. Sci. Policy, 13, 195-204, 2010.

30 EEA: Assessment of ground-level ozone in EEA member countries, with a focus on long-term trends, European Environment Agency, Copenhagen, DK, 2009.

EEA: Air Quality in Europe - 2012 report, European Environment Agency, Luxembourg, 2012.
ACPD

14, 1287-1316, 2014

\section{London's changing oxidizing \\ environment \\ E. von Schneidemesser \\ et al.}

Title Page

Abstract

Introduction

Conclusions

References

Tables

Figures

14

4

Back

Close

Full Screen / Esc

Printer-friendly Version

Interactive Discussion 
Fowler, D., Pilegaard, K., Sutton, M. A., Ambus, P., Raivonen, M., Duyzer, J., Simpson, D., Fagerli, H., Fuzzi, S., Schjoerring, J. K., Granier, C., Neftel, A., Isaksen, I. S. A., Laj, P., Maione, M., Monks, P. S., Burkhardt, J., Daemmgen, U., Neirynck, J., Personne, E., WichinkKruit, R., Butterbach-Bahl, K., Flechard, C., Tuovinen, J. P., Coyle, M., Gerosa, G., Loubet, B., Altimir, N., Gruenhage, L., Ammann, C., Cieslik, S., Paoletti, E., Mikkelsen, T. N., Ro-Poulsen, H., Cellier, P., Cape, J. N., Horvath, L., Loreto, F., Niinemets, U., Palmer, P. I., Rinne, J., Misztal, P., Nemitz, E., Nilsson, D., Pryor, S., Gallagher, M. W., Vesala, T., Skiba, U., Brueggemann, N., Zechmeister-Boltenstern, S., Williams, J., O'Dowd, C., Facchini, M. C., de Leeuw, G., Flossman, A., Chaumerliac, N., and Erisman, J. W.: Atmospheric composition change: ecosystems-atmosphere interactions, Atmos. Environ., 43, 5193-5267, doi:10.1016/j.atmosenv.2009.07.068, 2009.

Francis, X. V., Chemel, C., Sokhi, R. S., Norton, E. G., Ricketts, H. M. A., and Fisher, B. E. A.: Mechanisms responsible for the build-up of ozone over South East England during the August 2003 heatwave, Atmos. Environ., 45, 6880-6890, doi:10.1016/j.atmosenv.2011.04.035, 2011.

Gilman, J. B., Kuster, W. C., Goldan, P. D., Herndon, S. C., Zahniser, M. S., Tucker, S. C., Brewer, W. A., Lerner, B. M., Williams, E. J., Harley, R. A., Fehsenfeld, F. C., Warneke, C., and Gouw, J. A. D.: Measurements of volatile organic compounds during the 2006 TexAQS/GoMACCS campaign: industrial influences, regional characteristics, and diurnal dependencies of the OH reactivity, J. Geophys. Res., 114, D00F06, doi:10.1029/2008JD011525, 2009.

Goldan, P. D., Kuster, W. C., Williams, E., Murphy, P. C., Fehsenfeld, F. C., and Meagher, J.: Nonmethane hydrocarbon and oxy hydrocarbon measurements during the 2002 New England Air Quality Study, J. Geophys. Res.-Atmos., 109, D21309, doi:10.1029/2003jd004455, 2004.

Heal, M. R., Heaviside, C., Doherty, R. M., Vieno, M., Stevenson, D. S., and Vardoulakis, S.: Health burdens of surface ozone in the UK for a range of future scenarios, Environ. Int., 61, 36-44, doi:10.1016/j.envint.2013.09.010, 2013.

Hess, P. G. and Zbinden, R.: Stratospheric impact on tropospheric ozone variability and trends: 1990-2009, Atmos. Chem. Phys., 13, 649-674, doi:10.5194/acp-13-649-2013, 2013.

Im, U. and Kanakidou, M.: Impacts of East Mediterranean megacity emissions on air quality, Atmos. Chem. Phys., 12, 6335-6355, doi:10.5194/acp-12-6335-2012, 2012.
ACPD

14, 1287-1316, 2014

London's changing

oxidizing

environment

E. von Schneidemesser

et al.

Title Page

Abstract

Introduction

Conclusions

References

Tables

Figures

14

Back

Close

Full Screen / Esc

Printer-friendly Version

Interactive Discussion 
Jenkin, M. E., Watson, L. A., Utembe, S. R., and Shallcross, D. E.: A Common Representative Intermediates (CRI) mechanism for VOC degradation. Part 1: Gas phase mechanism development, Atmos. Environ., 42, 7185-7195, doi:10.1016/j.atmosenv.2008.07.028, 2008.

Jonson, J. E., Simpson, D., Fagerli, H., and Solberg, S.: Can we explain the trends in European ozone levels?, Atmos. Chem. Phys., 6, 51-66, doi:10.5194/acp-6-51-2006, 2006.

Kley, D., Geiss, H., and Mohnen, V.: Tropospheric ozone at elevated sites and precursor emissions in the United States and Europe, Atmos. Environ., 28, 149-158, 1994.

Kondo, Y., Takegawa, N., Matsui, H., Miyakawa, T., Koike, M., Miyazaki, Y., Kanaya, Y., Mochida, M., Kuwata, M., Morino, Y., and Shiraiwa, M.: Formation and transport of aerosols in tokyo in relation to their physical and chemical properties: a review, J. Meteorol. Soc. Jpn., 88, 597-624, 2010.

Le Treut, H., Somerville, R., Cubasch, U., Ding, Y., Mauritzen, C., Mokssit, A., Peterson, T., and Prather, M.: Historical Overview of Climate Change, in: Climate Change 2007: The Physical Science Basis. Contribution of Working Group I to the Fourth Assessment Report of the Intergovernmental Panel on Climate Change, edited by: Solomon, S., Qin, D., Manning, M., Chen, Z., Marquis, M., Averyt, K. B., Tignor, M., and Miller, H. L., Cambridge University Press, Cambridge, United Kingdom and New York, NY, 2007.

Melkonyan, A. and Kuttler, W.: Long-term analysis of $\mathrm{NO}, \mathrm{NO}_{2}$ and $\mathrm{O}_{3}$ concentrations in North Rhein-Westphalia, Germany, Atmos. Environ., 60, 316-326, 2012.

20 Monks, P. S., Granier, C., Fuzzi, S., Stohl, A., Williams, M. L., Akimoto, H., Amann, M., Baklanov, A., Baltensperger, U., Bey, I., Blake, N., Blake, R. S., Carslaw, K., Cooper, O. R., Dentener, F., Fowler, D., Fragkou, E., Frost, G. J., Generoso, S., Ginoux, P., Grewe, V., Guenther, A., Hansson, H. C., Henne, S., Hjorth, J., Hofzumahaus, A., Huntrieser, H., Isaksen, I. S. A., Jenkin, M. E., Kaiser, J., Kanakidou, M., Klimont, Z., Kulmala, M., Laj, P., Lawrence, M. G., Lee, J. D., Liousse, C., Maione, M., McFiggans, G., Metzger, A., Mieville, A., Moussiopoulos, N., Orlando, J. J., O'Dowd, C. D., Palmer, P. I., Parrish, D. D., Petzold, A., Platt, U., Poeschl, U., Prevot, A. S. H., Reeves, C. E., Reimann, S., Rudich, Y., Sellegri, K., Steinbrecher, R., Simpson, D., ten Brink, H., Theloke, J., van der Werf, G. R., Vautard, R., Vestreng, V., Vlachokostas, C., and von Glasow, R.: Atmospheric composition change - global and regional air quality, Atmos. Environ., 43, 5268-5350, doi:10.1016/j.atmosenv.2009.08.021, 2009.

Murphy, J. G., Day, D. A., Cleary, P. A., Wooldridge, P. J., Millet, D. B., Goldstein, A. H., and Cohen, R. C.: The weekend effect within and downwind of Sacramento - Part 1: Obser-
ACPD

$14,1287-1316,2014$

London's changing

oxidizing

environment

E. von Schneidemesser

et al.

Title Page

Abstract

Introduction

Conclusions

References

Tables

Figures

14

DI

Back

Close 
vations of ozone, nitrogen oxides, and VOC reactivity, Atmos. Chem. Phys., 7, 5327-5339, doi:10.5194/acp-7-5327-2007, 2007.

Parrish, D. D., Kuster, W. C., Shao, M., Yokouchi, Y., Kondo, Y., Goldan, P. D., Gouw, J. A. D., Koike, M., and Shirai, T.: Comparison of air pollutant emissions among mega-cities, Atmos.

$5 \quad$ Environ., 43, 6435-6441, 2009.

Parrish, D. D., Law, K. S., Staehelin, J., Derwent, R., Cooper, O. R., Tanimoto, H., VolzThomas, A., Gilge, S., Scheel, H.-E., Steinbacher,, M., and Chan, E.: Long-term changes in lower tropospheric baseline ozone concentrations at northern mid-latitudes, Atmos. Chem. Phys., 12, 11485-11504, doi:10.5194/acp-12-11485-2012, 2012.

10 RoTAP: Review of Transboundary Air Pollution: Acidification, Eutrophication, Ground Level Ozone and Heavy Metals in the UK, Summary for Policy Makers, Centre for Ecology \& Hydrology, Contract Report to the Department for Environment, Food and Rural Affairs, Wallingford, UK, 2012.

Shao, M., Lu, S., Lu, Y., Xie, X., Chang, C., Huang, S., and Chen, Z.: Volatile organic compounds measured in summer in Beijing and their role in ground-level ozone formation, $J$. Geophys. Res., 114, D00G06, doi:10.1029/2008JD010863, 2009.

Simpson, D., Benedictow, A., Berge, H., Bergström, R., Emberson, L. D., Fagerli, H., Flechard, C. R., Hayman, G. D., Gauss, M., Jonson, J. E., Jenkin, M. E., Nyíri, A., Richter, C., Semeena, V. S., Tsyro, S., Tuovinen, J.-P., Valdebenito, Á., and Wind, P.: The EMEP MSCW chemical transport model - technical description, Atmos. Chem. Phys., 12, 7825-7865, doi:10.5194/acp-12-7825-2012, 2012.

Tie, X., Geng, F., Guenther, A., Cao, J., Greenberg, J., Zhang, R., Apel, E., Li, G., Weinheimer, A., Chen, J., and Cai, C.: Megacity impacts on regional ozone formation: observations and WRF-Chem modeling for the MIRAGE-Shanghai field campaign, Atmos. Chem. Phys., 13, 5655-5669, doi:10.5194/acp-13-5655-2013, 2013.

Vieno, M., Dore, A. J., Stevenson, D. S., Doherty, R., Heal, M. R., Reis, S., Hallsworth, S., Tarrason, L., Wind, P., Fowler, D., Simpson, D., and Sutton, M. A.: Modelling surface ozone during the 2003 heat-wave in the UK, Atmos. Chem. Phys., 10, 7963-7978, doi:10.5194/acp10-7963-2010, 2010.

30 von Schneidemesser, E., Monks, P. S., and Plass-Duelmer, C.: Global comparison of VOC and CO observations in urban areas, Atmos. Environ., 44, 5053-5064, 2010.

\section{London's changing oxidizing environment \\ E. von Schneidemesser et al.}

Title Page

Abstract

Conclusions

Tables

14

4

Back

Full Screen / Esc
Introduction

References

Figures

$\rightarrow 1$

$>$

Close

Printer-friendly Version

Interactive Discussion 
von Schneidemesser, E., Monks, P. S., Gros, V., Gauduin, J., and Sanchez, O.: How important is biogenic isoprene in an urban environment? a study in London and Paris, Geophys. Res. Lett., 38, L19804, doi:10.1029/2011GL048647, 2011.

Warneke, C., Gouw, J. A. D., Holloway, J. S., Peischl, J., Ryerson, T. B., Atlas, E., Blake, D., 5 Trainer, M., and Parrish, D. D.: Multiyear trends in volatile organic compounds in Los Angeles, California: five decades of decreasing emissions, J. Geophys. Res., 117, D00V17, doi:10.1029/2012JD017899, 2012.

Weiss, M., Bonnel, P., Kühlwein, J., Provenza, A., Lambrecht, U., Alessandrini, S., Carriero, M., Colombo, R., Forni, F., Lanappe, G., Le Lijour, P., Manfredi, U., Montigny, F., and Sculati, M.: Will Euro 6 reduce the $\mathrm{NO}_{\mathrm{x}}$ emissions of new diesel cars? - Insights from on-road tests with Portable Emissions Measurement Systems (PEMS), Atmos. Environ., 62, 657-665, doi:10.1016/j.atmosenv.2012.08.056, 2012.

WHO: Health Aspects of Air Pollution with Particulate Matter, Ozone and Nitrogen Dioxide, Bonn, 2003.

Wilson, R. C., Fleming, Z. L., Monks, P. S., Clain, G., Henne, S., Konovalov, I. B., Szopa, S., and Menut, L.: Have primary emission reduction measures reduced ozone across Europe? An analysis of European rural background ozone trends 1996-2005, Atmos. Chem. Phys., 12, 437-454, doi:10.5194/acp-12-437-2012, 2012.

ACPD

14, 1287-1316, 2014

\section{London's changing oxidizing \\ environment}

E. von Schneidemesser et al.

Title Page

Abstract

Introduction

Conclusions

References

Tables

Figures

14

$\rightarrow 1$

4

Back

Close

Full Screen / Esc

Printer-friendly Version

Interactive Discussion 
Table 1. London site trends in \% per year for $\mathrm{NO}_{2}, \mathrm{NO}, \mathrm{CO}$, and $\mathrm{O}_{3}$ from 1998 through 2009. "nd" indicates no data was available; trend values in bold were statistically significant $(p \geqq$ $0.001)$.

\begin{tabular}{|c|c|c|c|c|c|}
\hline & Site & $\mathrm{NO}_{2}$ & NO & $\mathrm{CO}$ & $\mathrm{O}_{3}$ \\
\hline \multirow[t]{4}{*}{ Roadside } & A3 & $(0 \%)$ & $-11 \%$ & $-10 \%$ & nd \\
\hline & $\mathrm{BL}$ & $-4.6 \%$ & $-19 \%$ & $-19 \%$ & nd \\
\hline & $\mathrm{CR}$ & $-1.8 \%$ & $-7.2 \%$ & $-13 \%$ & nd \\
\hline & MR & $+1.6 \%$ & $-6.5 \%$ & $-12 \%$ & $+1.8 \%$ \\
\hline \multirow[t]{5}{*}{ Urban Center } & BB & $(-0.71 \%)$ & $-7.0 \%$ & $-9.9 \%$ & $+2.9 \%$ \\
\hline & HK & $-2.9 \%$ & $-8.3 \%$ & $-13 \%$ & $(+1.1 \%)$ \\
\hline & LH & $(-0.70 \%)$ & $-8.0 \%$ & & \\
\hline & SW & $-3.0 \%$ & $-9.7 \%$ & $-4.9 \%$ & $(+1.0 \%)$ \\
\hline & WW & $(+0.21 \%)$ & $-6.3 \%$ & nd & nd \\
\hline \multirow[t]{4}{*}{ Suburban } & $B X$ & $-1.2 \%{ }^{b}$ & $-3.0 \%$ & $-7.0 \%$ & $+2.0 \%$ \\
\hline & $\mathrm{HL}$ & $-2.0 \%{ }^{b}$ & $-6.4 \%$ & $-4.1 \%$ & $+2.2 \%$ \\
\hline & LE & $-3.2 \%$ & $-6.0 \%$ & nd & $+1.5 \%$ \\
\hline & ST & $(+0.099 \%)^{c}$ & $-7.9 \%$ & nd & nd \\
\hline \multirow[t]{4}{*}{ Urban Background } & BR & $-3.5 \%$ & $(-1.1 \%)$ & $-4.2 \%$ & $+3.7 \%$ \\
\hline & NK & $-3.1 \%$ & $-5.5 \%$ & $-1.5 \%{ }^{b}$ & $+3.2 \%$ \\
\hline & TD & $-3.1 \%$ & $(-0.94 \%)$ & $\mathrm{nd}$ & \\
\hline & WM & $-1.7 \%{ }^{a, c}$ & $-3.1 \%{ }^{c}$ & $-13 \%^{\mathrm{c}}$ & $+3.6 \%{ }^{\mathrm{c}}$ \\
\hline London ALL & & $-1.0 \%$ & $-6.0 \%$ & $-9.0 \%$ & $+1.3 \%{ }^{b}$ \\
\hline
\end{tabular}

$\mathrm{ALL}=$ all available data; if trend values are cited for the individual site, that data was included in the average. ${ }^{\mathrm{a}}=$ statistically significant $(p \leq 0.05),{ }^{\mathrm{b}}=$ statistically significant $(p \leq 0.01),{ }^{\mathrm{C}}$ indicates less than $10 \mathrm{yr}$ of data.
ACPD

$14,1287-1316,2014$

London's changing oxidizing

environment

E. von Schneidemesser et al.

\section{Title Page}

\section{Abstract}

Conclusions

Tables

14

4

Back

\section{Full Screen / Esc}

Printer-friendly Version

Interactive Discussion 


\section{ACPD}

14, 1287-1316, 2014

London's changing oxidizing environment

Table 2. Mean daily maximum $8 \mathrm{~h}$ ozone for June, July, and August. Slight discrepancies are owing to rounding.

\begin{tabular}{|c|c|c|c|c|c|c|c|}
\hline & & $\begin{array}{r}\text { Observed } \\
1998 \\
\left(\mu \mathrm{gm}^{-3}\right)\end{array}$ & $\begin{array}{r}\text { Observed } \\
2008 \\
\left(\mu \mathrm{gm}^{-3}\right)\end{array}$ & $\begin{array}{r}\text { Observed } \\
\Delta \mathrm{O}_{3} \\
\left(\mu \mathrm{gm}^{-3}\right)\end{array}$ & $\begin{array}{r}\text { Modeled } \\
\Delta \mathrm{O}_{3} \\
\left(\mu \mathrm{gm}^{-3}\right)\end{array}$ & $\begin{array}{r}\text { Modeled } \\
\Delta \mathrm{O}_{3} \\
\left(\mu \mathrm{gm}^{-3}\right) \\
\text { emissions }\end{array}$ & $\begin{array}{r}\text { Modeled } \\
\Delta \mathrm{O}_{3} \\
\left(\mu \mathrm{gm}^{-3}\right) \\
\text { VOC spec. }\end{array}$ \\
\hline Bloomsbury & urban center & 42 & 53 & 12 & 8.3 & 2.8 & -0.16 \\
\hline Eltham & suburban & 61 & 70 & 8.3 & 4.2 & 1.6 & -0.17 \\
\hline Hillingdon & suburban & 41 & 53 & 12 & 3.0 & 0.10 & -0.12 \\
\hline North Kensington & urban background & 60 & 69 & 9.0 & 4.6 & 0.90 & -0.16 \\
\hline Marylebone Road & roadside & 21 & 27 & 6.1 & 8.3 & 2.8 & -0.16 \\
\hline Average $^{a}$ & & $51 \pm 11$ & $61 \pm 9.3$ & $10 \pm 1.9$ & $5.0 \pm 2.3$ & $1.3 \pm 1.1$ & $-0.16 \pm 0.022$ \\
\hline
\end{tabular}

${ }^{a}$ No Marylebone Road.

E. von Schneidemesser et al.

\section{Title Page}

\section{Abstract}

Introduction

Conclusions

References

Tables

Figures

14

DI

Back

Close

\section{Full Screen / Esc}

Printer-friendly Version

Interactive Discussion 


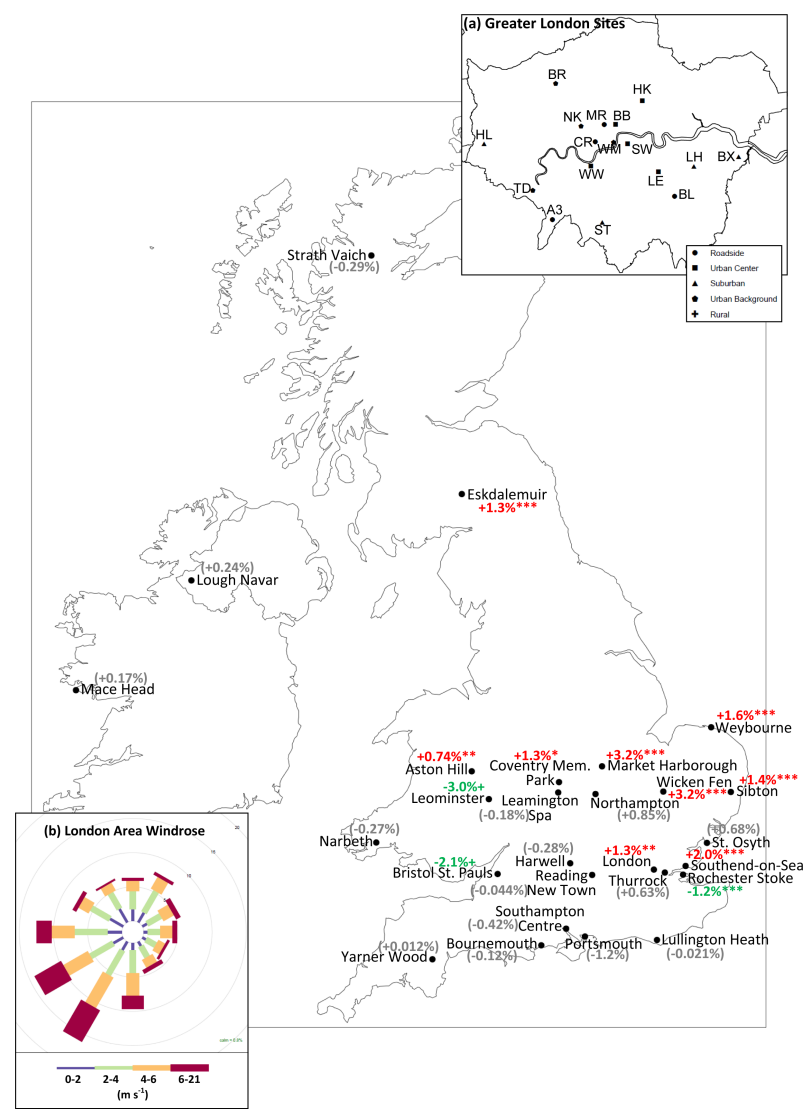

Fig. 1. Site locations (and ozone trends) for London and the surrounding area. Main figure area shows site locations and trends in ozone for the greater UK. Trends in red indicate increases in ozone, green decreases in ozone, statistical significance: ${ }^{* *} 99.9 \%,{ }^{* *} 99 \%$, * $95 \%,+90 \%$; trends in gray and parentheses were not statistically significant. (a) Site locations within greater London. See key for site types. (b) Windrose typical of the London area, data from 1998-2009.
ACPD

14, 1287-1316, 2014

London's changing oxidizing

environment

E. von Schneidemesser

et al.

\section{Title Page}

\section{Abstract}

Conclusions

Tables

14

Back

\section{Full Screen / Esc}

Printer-friendly Version

Interactive Discussion 


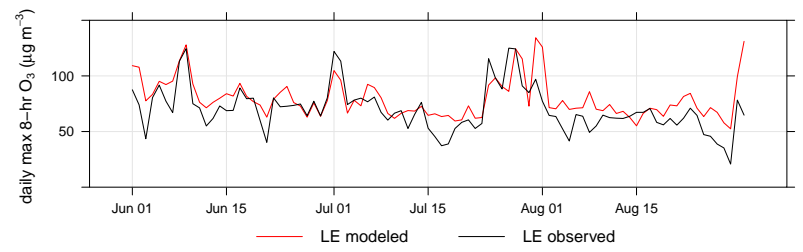

\section{ACPD}

14, 1287-1316, 2014

\section{London's changing oxidizing \\ environment}

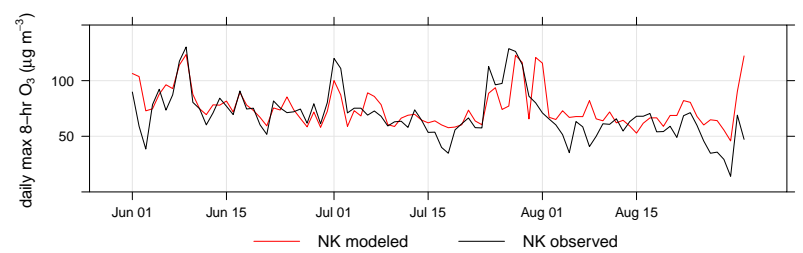

E. von Schneidemesser et al.

Title Page

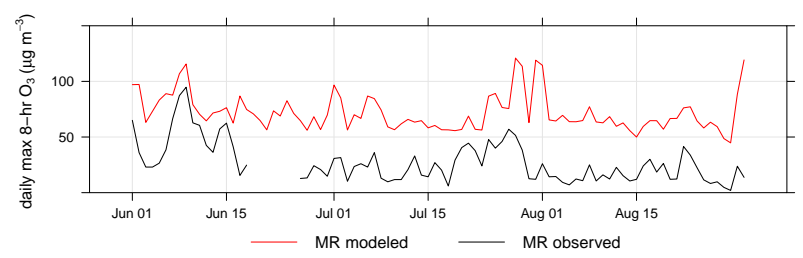

Abstract

Conclusions

Tables

14

Back

Introduction

References

Figures

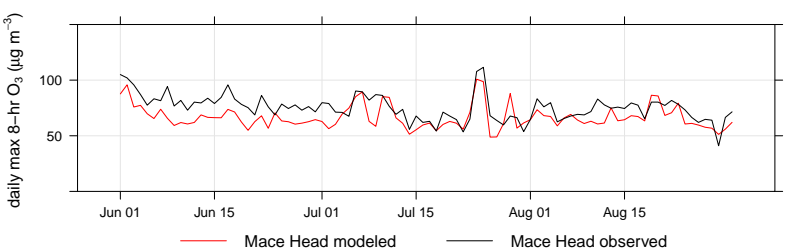

Fig. 2. Comparison of observed (monitoring data) and modeled daily maximum $8 \mathrm{~h}$ ozone in

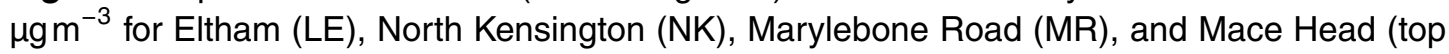
to bottom). Black lines are monitoring data, red lines model results.

\section{Full Screen / Esc}

Printer-friendly Version 


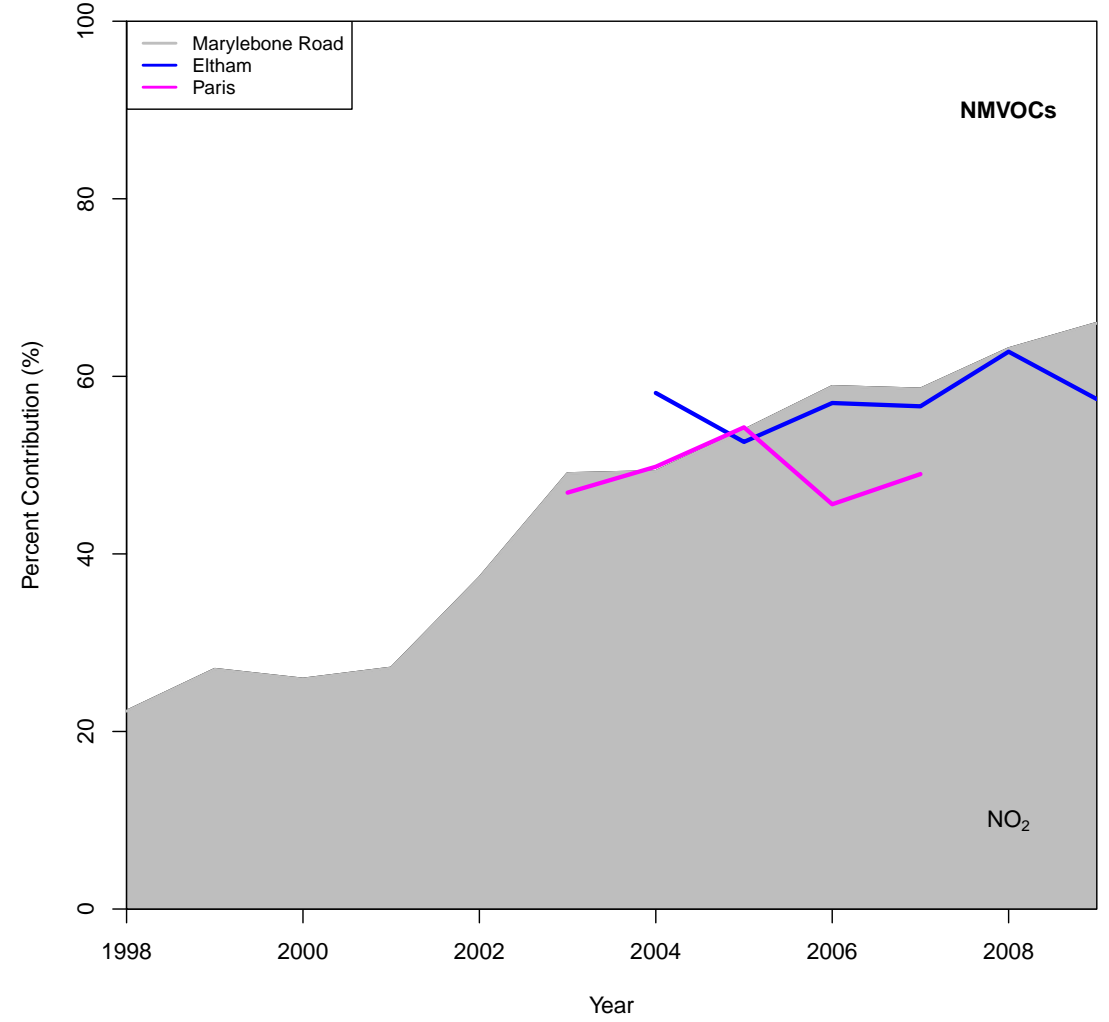

Fig. 3. Percent contribution to reactivity with respect to $\mathrm{OH}\left(R_{\mathrm{OH}}\right)$ from NMVOCs (above line, no shading) and $\mathrm{NO}_{2}$ (below line, gray area) from 1998 through 2009 for Marylebone Road. Eltham (suburban site) and Paris (urban background site) reactivity contributions are included for comparison; below these lines is the contribution from $\mathrm{NO}_{2}$, above from NMVOCs (as for MR, but without the shading).

\section{ACPD}

14, 1287-1316, 2014

London's changing oxidizing

environment

E. von Schneidemesser

et al.

\section{Title Page}

\section{Abstract}

Conclusions

Tables

14

Back

\section{Full Screen / Esc}

Printer-friendly Version 


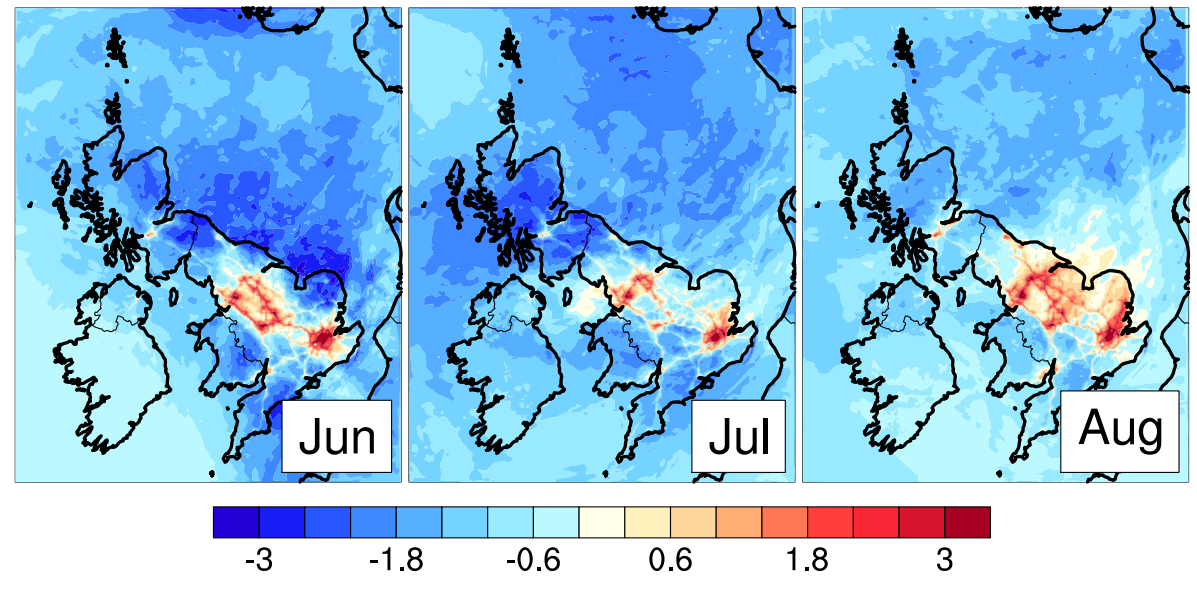

Fig. 4. The change in modeled surface monthly averaged maximum ozone (all hours) for June, July, August in $\mathrm{\mu gm}^{-3}$. The plots show the difference between the 2008 and 1998 basecase scenarios. Blue colors indicate decreases in ozone, red colors increases.

\section{ACPD}

14, 1287-1316, 2014

London's changing oxidizing

environment

E. von Schneidemesser et al.

\section{Title Page}

\section{Abstract}

Conclusions

Tables

14

Back

\section{Full Screen / Esc}

Printer-friendly Version 
Monthly max surface ozone $\left(\mu \mathrm{g} \mathrm{m}^{-3}\right)$

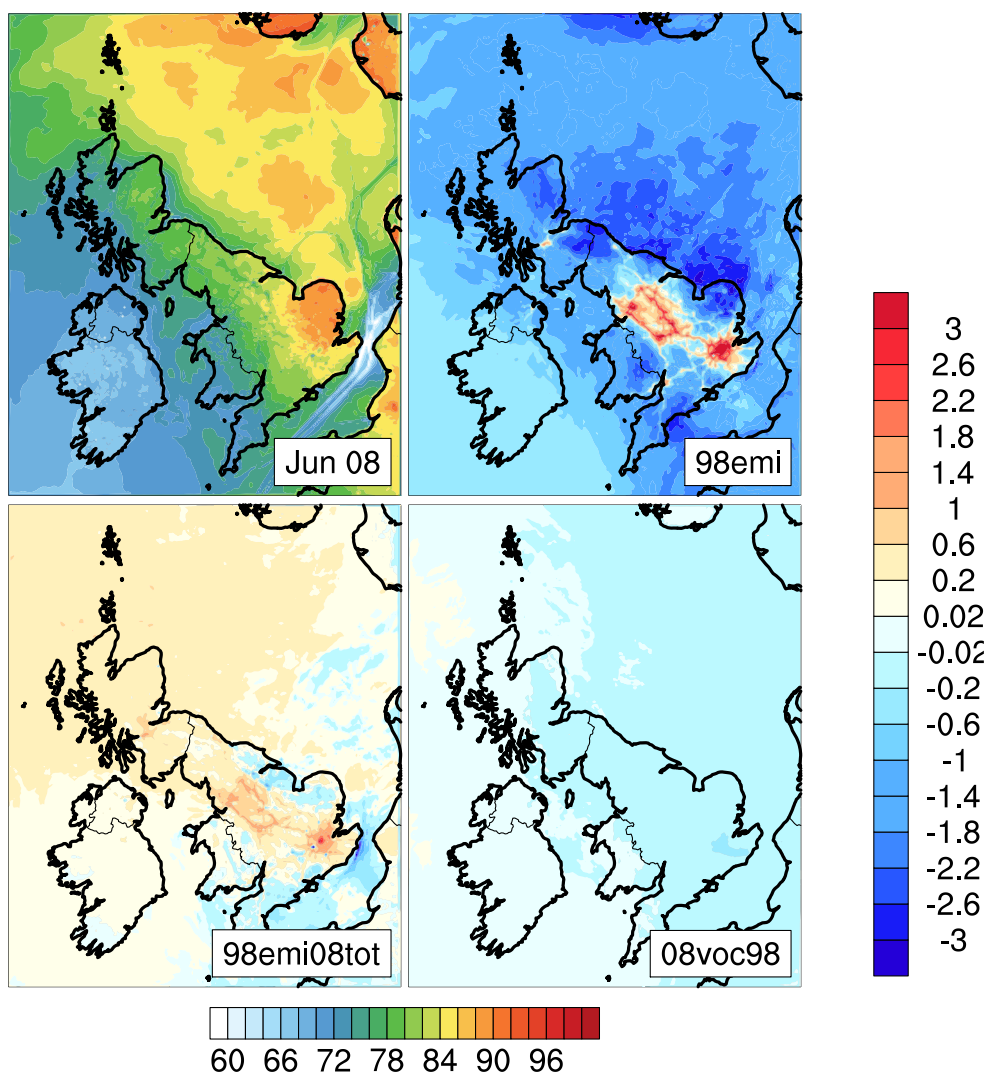

Fig. 5. (top left) The monthly average surface maximum ozone (all hours) for June 2008 in $\mu \mathrm{gm}^{-3}$. The change in modeled surface maximum ozone (all hours) as monthly averages for June 2008, showing the difference between the 2008 basecase scenario and (top right) the 1998 basecase scenario, (bottom left) the alternate emissions run, (bottom right) the VOC speciation run. Blue colors indicate decreases in ozone, red colors increases.

\section{ACPD}

14, 1287-1316, 2014

\section{London's changing oxidizing \\ environment \\ E. von Schneidemesser et al.}

Title Page
Abstract

Conclusions

Tables

14

Back
Introduction

References

Figures

$\Delta$

Close

\section{Full Screen / Esc}

Printer-friendly Version

Interactive Discussion 


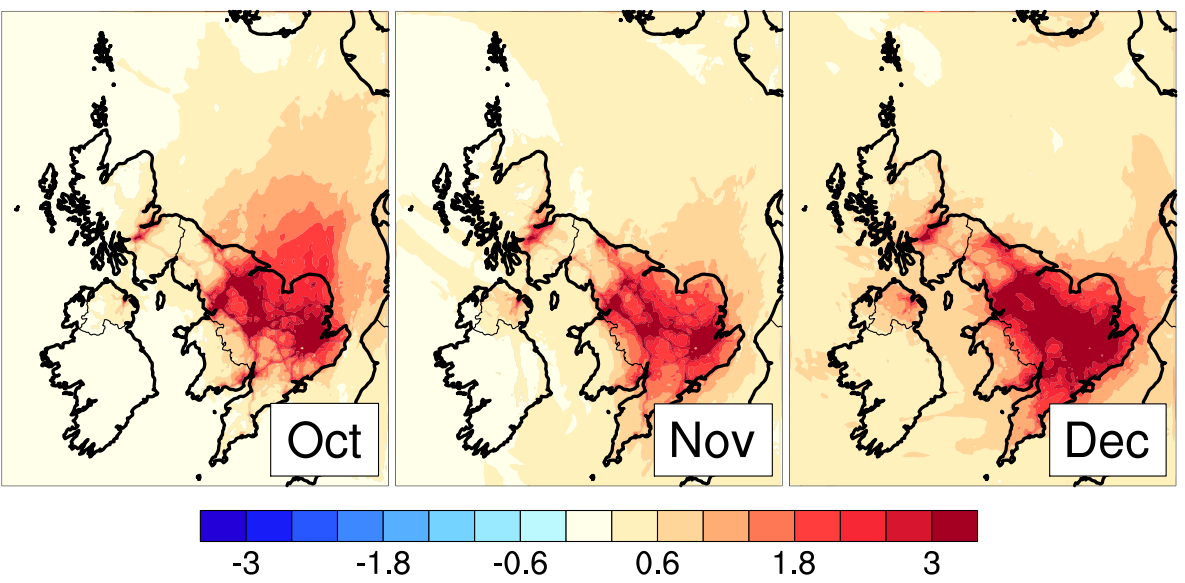

Fig. 6. The change in modeled surface maximum ozone (all hours) as monthly averages for

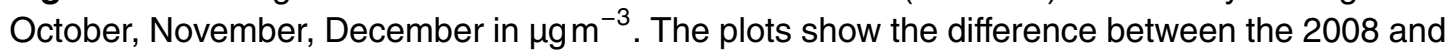
1998 basecase scenarios. Blue colors indicate decreases in ozone, red colors increases.
ACPD

14, 1287-1316, 2014

London's changing oxidizing

environment

E. von Schneidemesser

et al.

\section{Title Page}

Abstract

Introduction

Conclusions

References

Tables

Figures

14

$\Delta$

4

Back

Close

Full Screen / Esc

Printer-friendly Version

Interactive Discussion 